\title{
Mapping of 'Dakwah' Activity in Bandung City
}

\author{
${ }^{1}$ BAMBANG S. MA'ARIF, 2 NANDANG HMZ, ${ }^{3}$ ASEP AHMAD SIDDIQ, \\ ${ }^{4}$ SEVIYENTI FIKROH \\ 1,2,3 Fakultas Dakwah, Universitas Islam Bandung (Unisba), Jl. Ranggagading no. 8 Bandung, \\ ${ }^{4}$ Fakultas FISIP, Universitas Ronggolawe Tuban \\ email: 1basmar_ali@yahoo.com,ㄹninianteh58@gmail.com, \\ ${ }^{3}$ asepahmadsiddiq@gmail.com, ${ }^{4}$ syakurazalea@gmail.com
}

\begin{abstract}
Dakwah activity is carried out with a good way. To reach the right path, it is necessary to get data about map of dakwah activity in profile Bandung City. However, due to the missing data of dakwah activity profile in Bandung City, the Dakwah Communication which is carried out this time is depended more to the experience of communicators. The research aims to get the data of the profile of Dakwah Communication activity in Bandung. The problem of this research is to what extent the dakwah communication is accepted by the dakwah community in Bandung according to their socio-demographic identity. The method of this research is quantitative using the questionnaire for gathering the data. This study discovers various findings as follow: Distributing zone in Bandung which divided into three parts and socio-demography which help mapping the dakwah communication; Profile of occupied dakwah and communication to help mapping the dakwah communication; The modern communication media and traditional one, the art of extracurricular lecture and training, and act of dakwah which interest different dakwah community. This map of profile of dakwah communication can be used by dakwah communicator in Bandung to guide the effective dakwah communication.
\end{abstract}

Keyword: dakwah activity mapping, Socio-demography of dakwah, Dakwah Activity

\section{Introduction}

Bandung is a very interesting city for its nature or inhabitants. It is a very impression area, situated on hill region with a breezy wind that always makes it so pleasantly comfortable and puts its society in good condition. Overflow of the sun along a year makes the society energic. The inhabitants do not quickly tired, although they work all day long, whether they work outside or in their office. This condition makes its people not to be tired. The nature which is cool makes its people be silent and courtesy in facing various activities. The nature which is surrounded by hills that stretch out from mount Tangkuban Perahu to mount Malabar, and from mount Papandayan to region of Padalarang karst.

Bandung becomes the third biggest megapolitan in Indonesia -- after Jabodetabek (Jakarta, Bogor, Depok, Tangerang, and Bekasi) and Gerbang Kertasusila (Gersik, Bangkalan, Mojokerto, Surabaya, Sidoarjo, and Lamongan) -- whose people is dynamic and nonstop make creation day and night, and its community work creation continuously. In corners of the town there are many creative work result, which is decorated or marked by the spirit of nonstop innovation; showed by means of attractive thinking and work as well as useful for life. The characteristic of creative people makes its society always offers new creations in fashion, culinary and fun and smart agenda for the community of town. The religious class always seeks space of movement to promote the ability and characteristic of its activity.

Bandung has hills topography with contour of valley, slope of mountain and slope slightly of plain, with the height about 730 meters surface of sea. The condition of the nature has carried to rainfall which is relatively high, so that the temperature of the town is cool. Since the period of Ahmad Hassan, there are many creative religious thoughts which are constructively offered and

Received: April 07, 2017, Revision: August 03, 2017, Accepted: December 19, 2017

Print ISSN: 0215-8175; Online ISSN: 2303-2499. DOI: http://dx.doi.org/10.29313/mimbar.v33i2.2340.277-290

Accredited B based on the decree No.040/P/2014, valid on February, 18, 2014 until February, 18, 2019. Indexed by DOAJ, Sinta, IPI 
they makes Hassan's people interested to contribute innovation in growing the egaliter religious thinking.

Entering the year 2013, Bandung has new Mayor: Ridwan Kamil. This man, who is authorized by the party of Gerindra and PKS, has a good background education, graduated from Institut Teknologi Bandung (ITB), and got the magister program in the United State of America. Despite he is belonged to young class, his expert in world consultancy makes him a capable person in facing adaptation as well as acceleration with development demand.

A Dakwah communicator should be aware of condition of society whom the communicator called. At these times, however, dakwah could runs according to the will of the actor himself. It is needed that dakwah messages have the ability to make people smart, not only lulling them to sleep life (Muhtadi, 2012: 41). The dakwah communication is a matter of developing dakwah which put the factor of communication's arrangement (setting) and its media. The dakwah communicator should recognize the condition of the audience, especially from the socio-demographic side (covering region of occupancy, age, sex, education, work, income, hobby, understanding, and religious experience).

In accordance with this condition, Santi Indra Astuti in "Mimbar Jurnal Sosial dan Pembangunan" Unisba, (2000, vol.16 no. 3) stated,

In global era, dakwah faces some problems in disseminating Islamic loftiness thorought mass media. Phenomena about the circumstance changing confront $d a^{\prime} i$ to the new challenge: how to communicate through mass media effectively. Radio is among mass media which effectively penetrates its market and consumers. Compared with other media, radio is easily operated, high actually of massage or information and attractively audio to its listeners. So, dakwah through radio has effective effect to its audiences.

In response to global era, the dakwah communication ought to give integrated solution for the modern problems. Moslems need a kind of self-actualization until it can play a role in daily life. Dakwah activity is not isolated to the future development. In regard to the modern problems, Alex Sobur in "Mimbar Jurnal Sosial dan Pembangunan," Unisba, (2001, Volume 17 no. 4) stated,
Dakwah which merely reiterate to dogmatic and worship issues, should yield religious understood inability to pay role the interrelation between theological aspect, worships, and ethics to the human interaction (transaction). It's time to alter society's perception, that dakwah is not merely understood as verbally in conveying Islamic message, it must be widen that dakwah also can be conducted by writing, painting, and behavior. In contemporary understanding, dakwah can be done through all means and media, including educated society and developing.

Dakwah activity must reflect the audiences' pleasure upon the dakwah. The factor of socio-demographic is urge to be accurately mapped, in order to look its relation with their satisfaction (pleasure) upon dakwah in Bandung City.

\section{The Method Of Research}

The research is quantitative and its method is survey. The survey is carried out in region that determined as research location upon the respondent which become the sample. This research region is Bandung City, that it owns 5 regions (namely kawedanan [it is used in past time]). This distribution is appropriated with urban area administration which is legalized by the government of Bandung City. The population of this survey is the assembly of dakwah communication in Bandung, that the absort amounted 417 respondents.

The art of sampling in this survey takes (adopt) Multistage Cluster sampling. The researcher at the earlier determined various parameter, namely 1) zona, that the stretched distance from central town until the edge of area out of central town of Bandung city. 2) Classification of Bandung with the term of region, district, village and RW and RT. 3) Classification of occupancy area, comprises housing complex and non-housing complex.

Based on those 3 parameters, the researcher found stretched distance of Bandung city from the centre of town, namely 1) central town (within radius $0-6 \mathrm{~km}$ ) ; 2) countryside (within radius of $6,1-12 \mathrm{~km}$ ), and 3 ) outskirt (within radius of 12,1-20 km) or adjacent to District of Bandung directly. Zone of region in Bandung City, Cibeunying, Tegallega, and Ujung Berung. A number of District (kecamatan), namely Cicendo, Bandung Kulon, Panyileukan, and Cibiru. 


\section{The Art of Gathering Data}

Data is gathered using survey through questionnaire as prominent and supporting data. The concerned questionnaire is arranged by scale of Osgood respond to recognize aspiration, interest and enjoyment of the assembly with differentiation semantics concept, while SPSS (Statistical Package Social Science) used as a tool to count.

\section{Formulation of problem}

The focus of this survey is on map of dakwah activity in Bandung City which can be formulated as follows: How is the sociodemographic factor penetrates to dakwah activity in Bandung City, and its relation with satisfaction upon the component of dakwah that comprises dakwah communicator, content of communication message, and art as well as its media dakwah communication.

Dakwah communication always taking at one place, and in this research is located in Bandung, which focuses to the sociodemographic side. In other word, how we persuade the assembly of dakwah communication based on socio-demographic factor in Bandung. We need some information about the audiences' identity to guide our public speaking. Prophet Muhammad peace be upon him (pbuh), recommended Muslim to deliver speech according to receivers' capacity, especially demographic identity.

Identity is very important to focus our public speaking until it can persuade the public. "Persuasion is an important topic for communication study since success depends upon how well the persuader manipulates verbal and nonverbal symbol" (Infante, et al., 1990: 189). Meanwhile Shimp (2003: 117) told, "Persuasion as a part of daily life in all its facet. The practice of persuasion can be noble or deplorable. There is nothing wrong with persuasion per se; it is the practioners of persuasion who sometimes are at fault."

Certain factual information about the audience members can tell you a great deal. 'Demographic analysis' reveals data about the characteristics of a group of people, including age, sex, education, occupation, political allegiances, race, geographic location, and group affiliation (Hybels and Weaver II, 1992: 271, and Wood, Julia T., 2006: 346). Demographic identity covering region of occupancy, age, sex, education, work, income, hobby, kind of understanding, and religious expert. These things can be reflected in their pleasure upon dakwah. The factor of socio-demographic is urge to be accurately mapped in order to look its relation with their satisfaction upon dakwah in Bandung.

When we work with demographic information, we generalize about the entire audience; our generalizations might not be true of individual members (Hybels and Weaver II, 1992: 271). 'Demographic information about listeners is useful in two ways. First, it can help you adapt your speech to your listeners. Second, it can also be guided speakers in preparing a presentation that will interest and involve particular listener. Because we live in a multicultural world, effective speaker must be careful not to use examples that exclude some group' (Wood, Julia T., 2006: 346-347). "Demographic characteristics are a large identity-related social categories. People who share particular demographic characteristics also often share a set of historical or cultural references, and you might use some of these in your speech" (Alberts, Nakayama, Martin, 2007: 399).

With public speaking you can select a topic of great fascination to you, string together pretty words, and say them all out loud in an empty room. But you are not making a speech until you present your ideas to an audience (Andrews, Patricia Bradley, 1985: 55). Persuasive speaking is a process in which a speaker present a message intended to affect an audience in a specific way. Let us see how a persuasive speaker's procedure is contrasted with the informative speaker's (Verderber, Rudolph F., 1991: 270).

The prior research about dakwah communication conducted by A. Markarma (in Hunafa: Jurnal Studia Islamica, vol. 11 June, 2014 No. 1). He told that in the Qur'an perspective of dakwah communication (qaulan balîghan) is highly recommended. The ability of preacher to communicate effectively can affect the relative truth of thought of the audience (mustami'). The Koran insists that Islam is a perfect religion and must be socialized and internalized into the minds of its adherents in order to understand and to implement it consistently and continually. The $d a ' i$ must possess a good mastery of communication in order to be able to internalize the teachings of Islam into the mind of its adherents, through which they will behave as true Muslim. Meanwhile Syamsul Rijal wrote (in Studia Islamica, vol. 12 issue 3,2005 ) about the media of dakwah. He examines the Islamic issue presented 
by Sabily magazine from 1998 to 2004 . His study is mainly inspired by the resurgence of Islamist as a consequence of political liberalization that resulted from the fall of Soeharto in May 1998. The press freedom permitted by president Habibie has given Islamic media such as Sabily magazine the opportunity to operate relatively freely, unlike the restrictions faced during the New Order Era (Orde Baru). Thus, media take important rule in spreading of Islamic teaching and information.

The research aims to find data about mapping the profile of Dakwah activity in assembly in Bandung that based on its socio-demography. While the urgency of this research is that all information yielded of the research could be substance in determinating message, strategy, media and art of dakwah communication in Bandung City. So that dakwah could go effectively. Without mapping the dakwah activity in Bandung City, activist of dakwah does not have accurate data and information about his dakwah direction, until the dakwah communication is more trial and error characteristic.

The purpose of the research is to apply theory and practice characteristic. The theory use is to develop of dakwah communication relating to dakwah communication activity profile that based on socio-demographic factor. While the use of its yield in practice is that the information of the paper could become the guide for dakwah communicators and activists in planning dakwah that be interested by community of Bandung, until the dakwah communicator could communicate dakwah activity perfectly.

\section{Discussion}

Dakwah communication is a matter of delivering religious message to the society considering the condition of receiver and the use of media (B.S. Ma'arif, 2010: 21). Islamic Dakwah gives chance to its assembly to receive or to refuse. But the thing must be carried out by dakwah communicator "is delivering Islamic message in clear language" termed as al-Balāgh al-mubìn (QS. 3; 20, 16: 82, and 36: 18). Islamic Dakwah so endeavors the society that they can work optimally, creative autonomously, and offers comprehension and doing deeds. The dakwah becomes popular and spread out when using communication media. The dakwah communication receiver own dynamics conform with its socio-demographic factor.
The religious message contains prominent Islamic teaching, namely aqidah (islamic faith), shariat (Islamic law), and akhlaq [moral (Shaltut, 1966 and E.S. Anshari, 2001)] with its various derivative. For example, when a proselytizer wants to propagate or proselytizes to European society and America, he must use approach methods which much used in their social life and culture (Islahi, 1989: 60). The survey focussed on relation between proselytizer religious understanding with the communication character had much been carried out, among other is by M. Basyir. "The relation between educational factors with the theology understanding patroon on proselytizer in Ujung Pandang City (Study about God devine decree and human deed). Research of dissertation UIN Syahida, Jakarta, 1998.

The survey finding: there is a relation between respondent age and theology understanding pattern; the younger respondent tends to be liberal rational. The higher education level of respondent, the more liberal rational. The general education kind trends rational theology compared with those who take diniyyah education. The Nahdlatul Ulama (NU) follower trend to more traditional theology (ahlussunnah walJamā'ah), the Bugis ethnic and Makassar are more active than Maduranesse.

Since 2002 the researcher has been carrying out various surveys on Dakwah Communication in Bandung. Islamic Dakwah owns the spirit of Amr Ma'ruf (injunction of good deed) and Nahyi Munkar (prohibition of ignores). The dakwah is a matter of large framework (macro), continuous, and very large, larger than carrying out tabligh and lecture. The dakwah is a matter of effort to call human toward the path of God, the straight path (Fadhlullah, 1997: 10). The dakwah invites people who are muslims to be sure in order to carry out the religious teaching that they embrace (Pranggono, 2006: 12). Miftah Faridl (2008:1) explains that the dakwah is not only lecture.

\section{The understanding about "Amr Ma'ruf and Nahyi Munkar"}

Amr ma'ruf and nahyi munkar is pointing the same direction to command to good thing and prevent (prohibit) the ignored. The authority (ruler) gives the arrangement and enforcement of restriction the motorbike gang, engage in gang fight among citizen, restraint rotation of strong 
drink and gambling.

The authority must not proselytize with his voice, but his signature is able to take Islamic ummat to be avoided from bad life cause as a consequence from the mistakes of motorbike gang, engage in gang fight among citizen, and from killed by poisonous drink. The dakwah is always facing challenge and obstacle, but if the communicator always to approach (taqarrub) to Allah and does good (pious/viruous/godly) deeds he will be exist. Abdurrahman (2010: 318) clarifies, "However great typhoon (hurricane) is, will not cause collapse/demolish banyan tree if it is not helped earlier by termite which makes it porous/spongy in its tree trunk, or at the water decays its roots from the bottom. The tree whose root is spongy or its trunk is porous, the tree will collapse although no the wind blows up. Both village and city need entertainment, information, health and education. The Dakwah must touch all aspect of life.

\section{The Dakwah and Culture}

The community does not live in empty space of socio-cultural. In many things, they always interact with various component of life. The people is always influenced by its culture. The narrative or story of the nine pious religious leaders (wali songo) who passed in spreading Islam teaching in the island of Java is attend to Rasulullah may peace be upon him (mpbup), is one prominent figure in Islam. His step in spreading Islam did not know getting tired. Although he much faced challenges and obstacles, but Rasulullah Mpbup always be consistent in his strugle (ijtihâd and mujâhadah] war against deviation from the true principles of religion).

After the prophet (may peace be upon him) carried out dakwah sirriyahly along 3 years, he continued his dakwah jahriyyahly. In month of Shawal 10 of his being prophet or at the end of month May at the beginning or June 619 the prophet went to Thaif, around 60 miles from Makkah. He came there accompanied by his adopted son Zaid ben Harithah. The propet proselytized, but here a hard refusal was against him ( Al-Mubarakfuri, 2001:178). A matter of one example of approach that can be followed (imitated) by recent dakwah communicator. From the psychology side, the dakwah in seen effective (Faizah and Effendi, 2009: xx) if it can give understanding to the community (those who are proselytized) on what is proselytized.

\section{The Dakwah communicator}

A proselytizer should possess three prominent characteristics, namely knowledge, soft and silent (Taimiyah, 2001: 99). Besides, it should be accompanied real deed which softens their heart (Zahrah, 1994:152). The prophet is a prominent dakwah figure. In his explanation he used means of communication. Sometimes he used his both hands and face expression (not dramatizing or pretending). Sometimes he made a scratch on the earth to explain what he wanted to wish, for example, the prophet described for his companion sirāth Allah (path of Allah) by a straight line and satan path by a bent lines (Abdul Khaliq, 1996: 26).

Other prominent dakwah communication is effective and influent dakwah (Abd. Rahman Dudung, 2009: 91). The dakwah effectivity is accepted well by dakwah community, while it will be efficiency if the dakwah delivers good understanding and deed. The prophet may peace be upon him, makes use all method growing in social life and cultural on their religion which be proved (evidenced) to support the importance of dakwah (Islahi, 1989: 59). For example. He often visited the head of ethnic in Makkah and Thaif to call them to Islam.

The dakwah communicator is demanded to be sophisticated as public speaking. Komala (2013: 197) explains, "Public speaking is the art of speaking before public about a topic orally, with the purpose to influence, invite, educate, change the opinion, explain, and give the information." Komala later, (2013: 199) explains, the visual communication is knowledge that studies the concept of communication and creative expression, art and media to convey message and idea visually, including audio.

\section{Content of Dakwah Communication message}

Communication satisfied will bridge persuasion, whose of its purpose is to change .(Muhtadi, 2012: 46). If the satisfaction appears, it will carry positive influence appears in community life. Its messages look like the message sourced to Al-Quran and Al-Sunnah: aqidah, syari'ah and akhlaq. With the good moral, a Moslem will reach mahabbah from Allah and his apostle together with the believer (Wahyudi, 2013: 57). Ethics is very important to be discussed in dakwah communication, because the hadits explains, innamā buitstu li-utammima makārim al 
akhlāq."

Islam is progress in the economy, but without the other subject loose and destroy the nature. The economy ethics in Islam is built because of the religious moral value becomes synergy with the rationalization of win-loss calculation, so that balance occurred between these two basic elements (Wahyudi, 2013: 51).

The material of akhlaq is practiced by Moslem with the attention to substantial teaching known as Tasawuf. It more stresses to spiritual and inner preparation (Frager, 2012: 177). The subject of Fiqh brings good and useful behavior. Among the subject of Fiqh which bring to debate is tawasul, for there is a forbidden as well as allowed in tawassul. The forbidden tawassul is what be carried out by means of the dead men (Zakaria, 2005: 95). While the group of Nahdliyyin stated that all the tawassul is "permitted," because they consider that those dead men gazed are life (QS. 2: 154).

\section{Media and art of Dakwah Communi- cation.}

The most prominent feature of dakwah communication is communication media in conveying its message. The view of McLuhan 'Medium is message" becomes a guide of communication activity. Media is in a form of electronic as well as print. All media own specific in conveying message. All messages which launched would be appropriated with its conveying media. The art of communication links with the way of conveying message.

\section{The profile of Dakwah Communica- tion}

The profile of Dakwah is a matter of total illustration and agenda on dakwah process which carried out by proselytizers. The dakwah process concerned will express a common "pattern". The pattern of dakwah is a matter of activity in dakwah which runs continuously, together with the need of community. So that the outgoing dakwah could be evaluated objectively, and consider the real condition.

\section{The Result of the Survey}

We have analysed the result of survey which is the data taken from inquiry is divided in form of frequent Table, then explained and discussed upon the Table.
Analysis and Data of Respondent

Table 1 Sex of Respondent

\begin{tabular}{|c|c|c|}
\hline No & Sex & Frequency (Percentage) \\
\hline 1. & Male & $239(57)$ \\
\hline 2. & Female & $178(43)$ \\
\hline \multicolumn{2}{|c|}{ Total } & $417(100)$ \\
\hline
\end{tabular}

Source: Research: Bambang S.Ma'arif, Cs, 2014

Table 1 shows the sex of respondent, in which that the big part of respondent is male, namely $57 \%$. If we look from the total, the difference of sex of respondent does not striking (glaring). This shows whether male of female own/have same interesting in the activity of (Islamic religious lecture) in Badung city.

Table 2

Age of Respondent

\begin{tabular}{|c|c|c|c|}
\hline No & Age & Frequency (Percentage) & \\
\hline 1. & $17-24$ & 59 & $14 \%$ \\
\hline 2. & $25-35$ & 88 & $21 \%$ \\
\hline 3. & $36-46$ & 125 & $30 \%$ \\
\hline 4. & $47-56$ & 94 & $23 \%$ \\
\hline 5. & $57-64$ & 37 & $9 \%$ \\
\hline 6. & 14 & $3 \%$ \\
\hline \multicolumn{2}{|c|}{ Total } & 417 & $100 \%$ \\
\hline
\end{tabular}

Source Research Bambang S.Ma'arif, CS. 2014

The Table 2 shows the age of respondent the most is on $36-46$ years $(30 \%)$ and between range of age $47-56$ years (23\%). This age is a matter of range age productive. Next is between $25-35$ years $(21 \%)$.

Table 3 The Education of Respondent

\begin{tabular}{|l|l|l|l|}
\hline No & Education & Frequency & Percentage \\
\hline 1. & $\begin{array}{l}\text { SMP (Secondary } \\
\text { School) and the } \\
\text { Same }\end{array}$ & 53 & $13 \%$ \\
\hline 2. & $\begin{array}{l}\text { SMA (High } \\
\text { Secondary) and } \\
\text { the Same }\end{array}$ & 225 & $54 \%$ \\
\hline 3. & Diplome & 46 & $11 \%$ \\
\hline 4. & Academicent & 71 & $17 \%$ \\
\hline 5. & $\begin{array}{l}\text { Post Academi } \\
\text { cent }\end{array}$ & 12 & $3 \%$ \\
\hline 6. & Other & 5 & $1 \%$ \\
\hline 7. & No answer & 5 & $1 \%$ \\
\hline & Total & 417 & $100 \%$ \\
\hline
\end{tabular}

Source: Research Bambang S. Ma'arif, CS, 2014 
Table 3. shows about education of respondent in Bandung city, namely from group of education of High Secondary school and the same amount 225 persons (54\%), is a matter of most respondent community, academicent $17 \%$, and secondary school and the same $11 \%$.

Tabel 4

Job (occupation) of Respondent

\begin{tabular}{|c|c|c|c|}
\hline No & Occupation & Frequency & Percentage \\
\hline 1. & $\begin{array}{l}\text { Wife of } \\
\text { Neighbourhood } \\
\text { Assoc }\end{array}$ & 106 & $25 \%$ \\
\hline 2. & $\begin{array}{l}\text { PNS (Provision } \\
\text { Government } \\
\text { Employee) }\end{array}$ & 38 & $9 \%$ \\
\hline 3. & $\begin{array}{l}\text { Pegawai } \\
\text { Swasta (Private } \\
\text { Employee) }\end{array}$ & 121 & $29 \%$ \\
\hline 4. & $\begin{array}{l}\text { Wirausaha } \\
\text { (Businessman) }\end{array}$ & 47 & $11 \%$ \\
\hline 5. & Student & 52 & $12 \%$ \\
\hline 6. & $\begin{array}{l}\text { Pensiunan } \\
\text { (Retired) }\end{array}$ & 39 & $9 \%$ \\
\hline 7. & Others & 14 & $3 \%$ \\
\hline & Total & 417 & $100 \%$ \\
\hline
\end{tabular}

Resource: Research Bambang S.Ma'arif, CS, 2014

Table 4 shows the data about occupation of respondent in Bandung. The most Assembly (Jemaah) who participate in dakwah communication activity in Bandung is Provisional Employee 121 persons (29\%). Then the wife of Neighbourhood Association reaches $25 \%$ (or a quarter) of respondent. While the third sequence is pupil and student.

\section{Tabel 5 \\ Participation in Religious Social Organization}

\begin{tabular}{|l|l|c|}
\hline No & Organization & Frequency \\
\hline 1. & Nahdlatul Ulama (NU) & 64 \\
\hline 2. & Muhammadiyah & 9 \\
\hline 3. & Persatuan Islam (Persis) & 11 \\
\hline 4. & Persatuan Umat Islam (PUI) & 1 \\
\hline 5. & Jamaah Tabligh & 5 \\
\hline 6. & Salafy & 0 \\
\hline 7. & Hizbut Tahrir Indonesia (HTI) & 0 \\
\hline 8. & Others & 24 \\
\hline
\end{tabular}

Source: Research Bambang S. Ma'arif, Cs, 2014

Table 5 shows the data, among who follow of Religious Social Organization, of the result of this survey about participation of respondent in Religious Social Organization, from 114 respondents who participate
Community Social Organization in Bandung city spread in organization of NU, Persis, Muhammadiyah, Jamaah Tabligh, and PUI. It look that the religious Social Organization who are the most participants of respondent are NU totaled 64 persons, then Persis and Muhammadiyah. (Note: in fact, this table is continuous from the number before, but not mentioned in this paper, ie not all of the respondent are members of religious social organization, but among who attend to religious social organization).

This condition shows that assembly of Islamic teaching is heterogenous, and those proselytizers when conveying the material of prominent point, so that not to involve in dispute in arena (circle) of assembly.

Tabel 6

Source of Jemaah Religious Information

\begin{tabular}{|l|l|l|}
\hline No & Source & Frequency \\
\hline 1. & Pengajian (Islamic teaching) & 323 \\
\hline 2. & Book and literature & 227 \\
\hline 3. & Cassette/ CD & 134 \\
\hline 4. & $\begin{array}{l}\text { Magazine, newspaper, tabloid, } \\
\text { bulletin }\end{array}$ & 57 \\
\hline 5. & SMS (religious messages) & 51 \\
\hline 6. & TV & 13 \\
\hline 7. & Radio & 9 \\
\hline 8. & Social Media (online) & 12 \\
\hline Note: Allowed to fill more than one item \\
\hline \multicolumn{2}{|l}{} \\
\hline
\end{tabular}

Source: Research Bambang S.Ma'arif, Cs, 2014

Table 6 shows source of respondent religious information in Bandung city. Communicans get information of religious with various source whether direct by means of Islamic teaching, electronic media like CD, SMS with religious message, TV, Social Media (online), and Radio, or from print media like Book, Magazine, Newspaper, Tabloid, Bulletin.

\section{Table 7}

Periode of Watching Tv Time every day

\begin{tabular}{|l|c|c|}
\hline No & $\begin{array}{c}\text { Period of } \\
\text { Watching time }\end{array}$ & $\begin{array}{c}\text { Frequency } \\
\text { (Percentage) }\end{array}$ \\
\hline 1. & $0,5-1$ hour & $77(18)$ \\
\hline 2. & $1-2,5$ hour & $197(47)$ \\
\hline 3. & $2,5-4$ hour & $106(25)$ \\
\hline 4. & $4-6$ hour & $19(5)$ \\
\hline 5. & Others & $18(4)$ \\
\hline \multicolumn{2}{|c|}{ Total } & $417(100)$ \\
\hline
\end{tabular}

Source: Research Bambang S.Ma'arif, Cs 2014 
Table 7 shows data about duration of watching tv by respondent. The duration of respondent 197 persons (47\%) watch television at the range $1-2,5$ hours (47\%), $2,5-4$ hours reach $25 \%$ (a quarter). But there is also $5 \%$ (one per twenty) which reach 4 - 6 hours or heavy viewer.

Table 8. Interesting of Dakwah Communication by Film and Series.

\begin{tabular}{|l|l|c|}
\hline No & Kind & Frequency (Percentage) \\
\hline 1. & Very Agree & $24(6)$ \\
\hline 2. & Agree & $259(62)$ \\
\hline 3. & Occasionally & $110(26)$ \\
\hline 4. & Disagree & $22(5,3)$ \\
\hline 5. & VeryDisagree & $2(0,5)$ \\
\hline \multicolumn{2}{|l}{ Total } & $417(100)$ \\
\hline
\end{tabular}

Source: Research Bambang S.Ma'arif, Cs, 2014

Table 8 shows attractive power of dakwah communication by means of Film and Series at the assembly in Bandung city, namely 259 persons (62\%) agree Film and Series attract their attention. While $26 \%$ explain occasionally and very agree reach $6 \%$. But there is $5 \%$ which do not agree at making film and series as means of dakwah. That is mean same with one per twenty of dakwah communican who are not interested by film media and series by means of dakwah.

The condition of Socio-demography of assembly in three Region Zone of Bandung city.

\section{Zone of Central Town Diagram}

Based on Diagram 1 about the Profile of Communicator in Centre Town Zone, which divided to three classifications, it can be explained that the Profile of Dakwah Communicator who are enjoyed by communican are Dakwah Communican in Central Town (who interact with market) satisfied dakwah communication whose language is soft, use the easy logic, produces a masterwork in society, Figure who has soft emotion, and well educated.

While the Communican in Central town (not interact with Market) like the communicator profile who has soft emotion, uses easy logic (to understand), polite language, and produces a masterwork in society. While the communican in Central Town [complex National Army (TNI) Air
Force $(\mathrm{AU})$ ] satisfied dakwah communicator who produce a master work in society, uses polite language and logic which is easy to understood, soft emotion, offers assist to assembly.

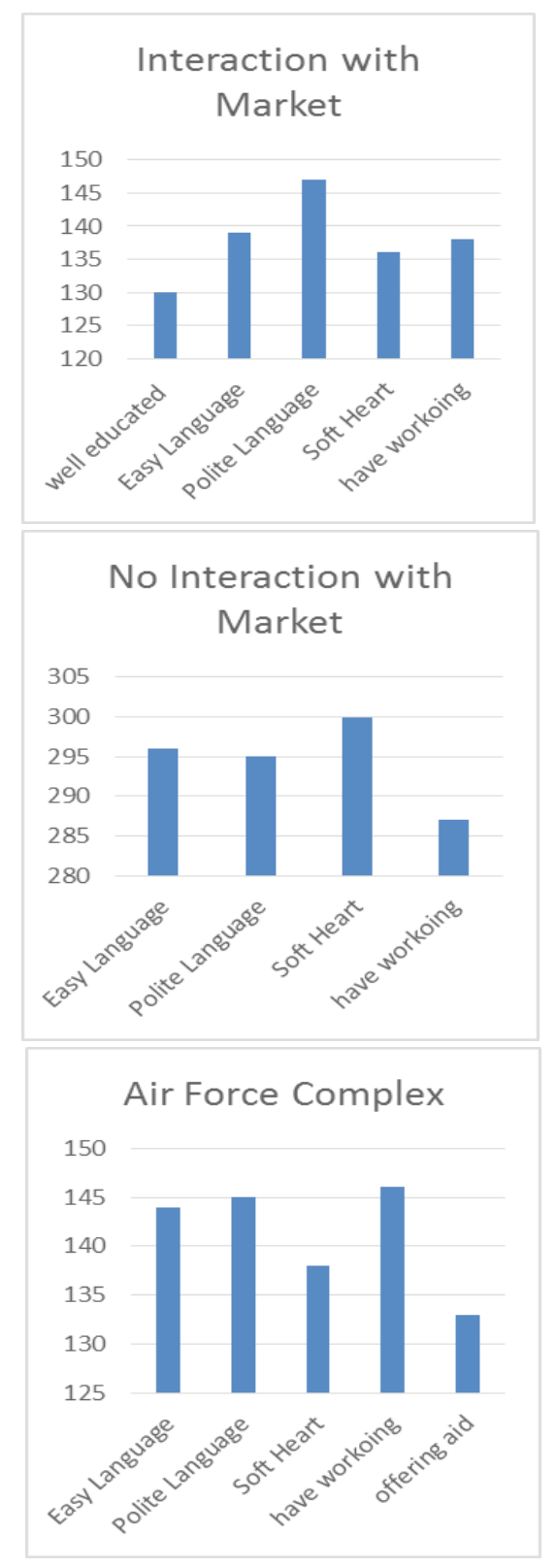

Source: Research Bambang S.Ma'arif, Cs, 2014

\section{Diagram 1. Profile of Communicatior Dakwah}

\section{Zone of Country Side}

Based on diagram Profile Communication Zona Countryside which divided to three (3) occupancy classification, it could be categorized Dakwah Communication Profile whom communican hope, namely dakwah communication in Countryside (Complex 
Occupancy) satisfied Dakwah Communicator Profile who has polite language, uses easy logic, soft emotion, analyzes the actual and modern life problem, and produces a masterwork in society.

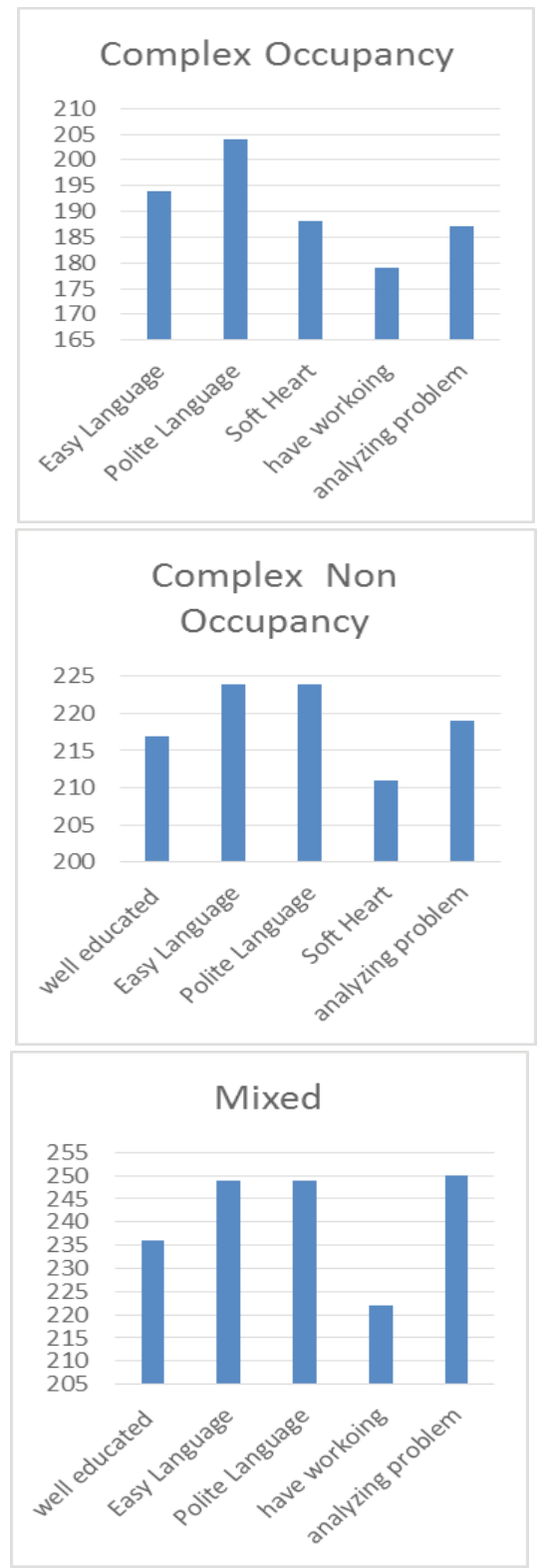

Source: Research Bambang S.Ma'arif, Cs, 2014

\section{Diagram 2. Profile of Dakwah Coomunican}

Dakwah Communican in Countryside (non-Complex Occupancy) satisfied dakwah communicator profile who uses logic which easy to be understood, polite language, analyzes the actual and modern life problem, well educated, soft emotion. While dakwah communican in countryside (occupancy complex which has Mixed) satisfied dakwah communicator profile who analyzes the actual and modern life problem, uses easy logic, polite language, has well education, and analyzes the actual and modern life problem.

\section{Zona of Edge of Town (more Out- skirts /Gedebage)}

Outskirts (Gedebage) which is devided to 2 classifications of occupancy, Profile of Dakwah Communicator which is satisfieded: (a) Zona of Edge of Town (More Outskirts/Pinggiran kota sekali (Complex of Occupancy): Polite Language, use the easy logics (to be understood), soft heart of Proselytizer, well Education, and skilled Proselytizer, and (b) Zona of Edge of Town (More Outskirts of Complex nonOccupancy): Soft heart of Prosellytizer, Polite language, attractive Proselytizer, easy logics to be understood, well educated, and skilled Proselytizer.

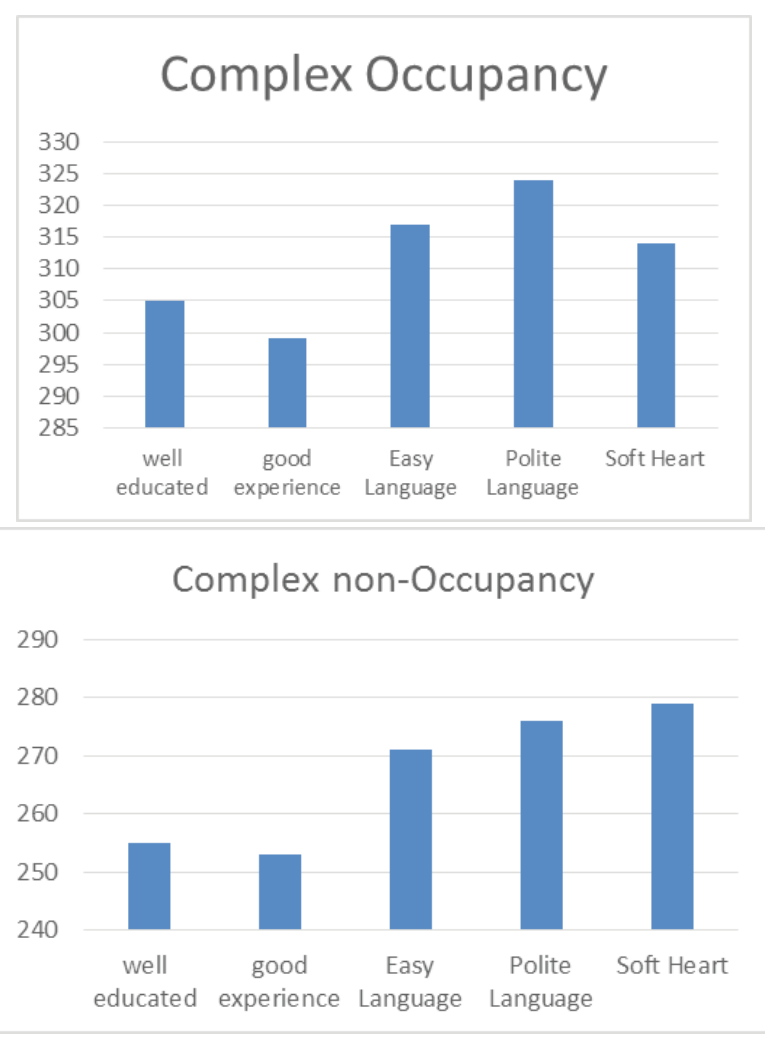

Source: Research Bambang S.Ma'arif, Cs, 2014

DIAGRAM 3. Profile of Dakwah Commuicator

\section{Zone Central Town}

Based on Diagram of Content of Dakwah Communication Message in Zone Central town which divided to 3 classifications of occupancy, it can be explained that the Content of Dakwah message which be satisfied, can be explained that Dakwah communican in Central town (interaction with 
Market) are aqidah, general election with the theme "the dedicated leader", religious teaching with the concrete examples, pillar of iman, "detriment of worship with riya (jealously proud or haughty)."

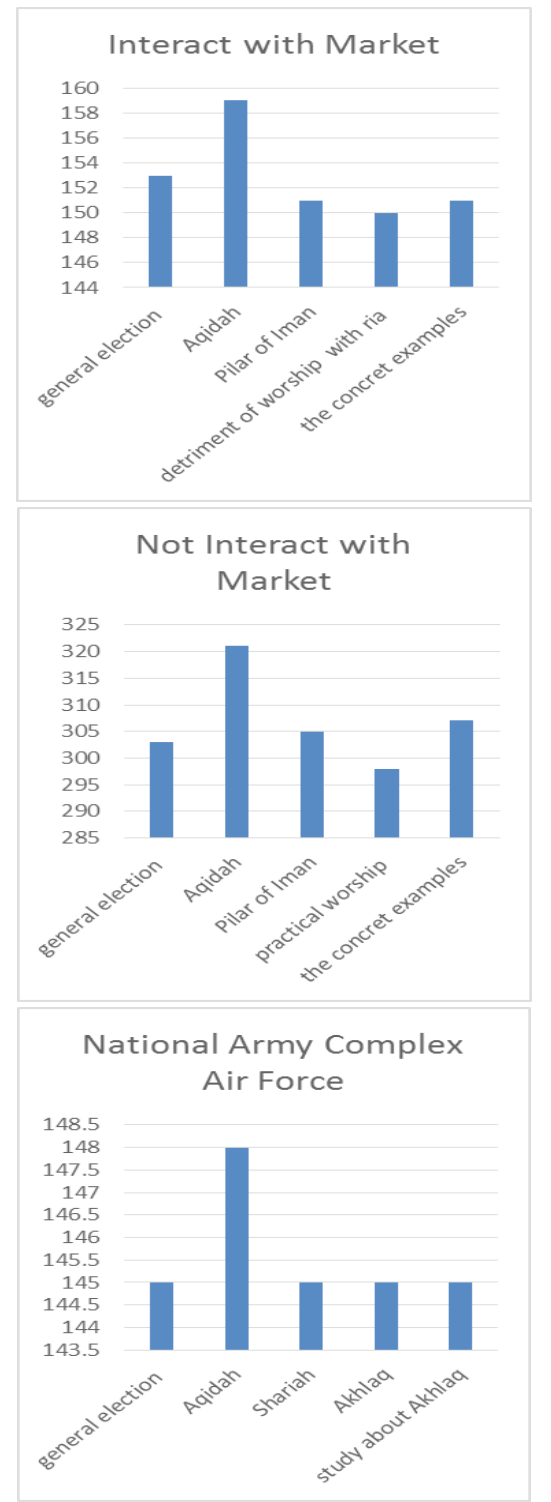

Source: Research Bambang S.Ma'arif, Cs, 2014

\section{Diagram 4. Content of Dakwah Communication Message}

The Dakwah Communican in Central town (Not interaction with Market) satisfied: belief or faith (aqidah) message, analyzing religious teaching with the concrete examples, pillar of iman, general election with the theme "the dedicated leader," practical worship helps to raising ibadah. While the Dakwah communican in Central town [National Army Complex (TNI) Air Force (AU)] satisfied subject: Aqidah, general election and "the dedicated leader," Shari'ah Islam becomes foundation of the truth of deed of devotion, Moral or Akhlaq (inner condition and society order), Akhlak forms character.

\section{Zona Countryside}

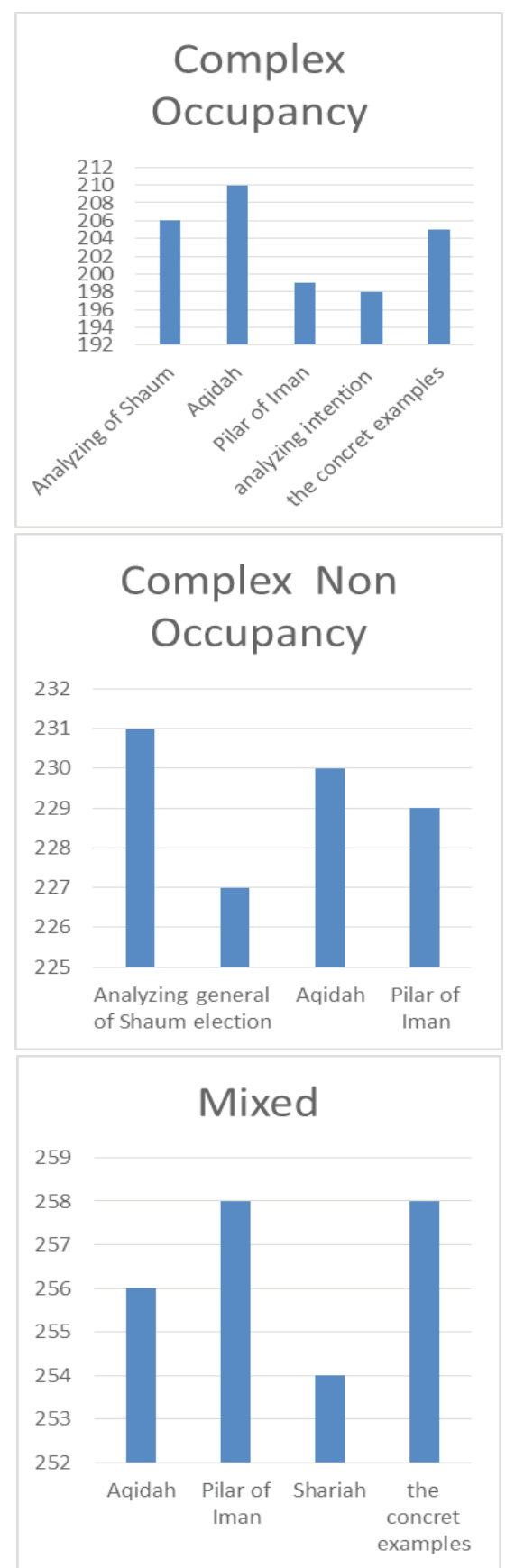

Source: Research Bambang S.Ma'arif, Cs, 2014

Diagram 5. about satisfaction of Dakwah Communican of the content Dakwah

In Diagram 5 Communication based on zone classification and occupancy region, namely in Countryside (Complex of Occupancy) satisfied subject: Ramadhan and analyze of shaum, analyzing religious 
teaching with the concrete examples, Pilar of Iman, and analyzing intention (niat), and General Election and "Dedicated Leader." While in non-occupancy complex they satisfied subject: Ramadhan and analyze of shaum, aqidah/faith, pillar of iman, and General Election and "Dedicated Leader". While the dakwah communican in Occupancy complex (which has mixed) satisfied subjects: Pilar of Iman, analyzing religious teaching with the concrete examples, Faith (Aqidah), and Shari'ah Islam becomes the foundation of the truth of deed of devotion.

\section{Zona of Edge of Town (more Outskirts / Gedebage)}

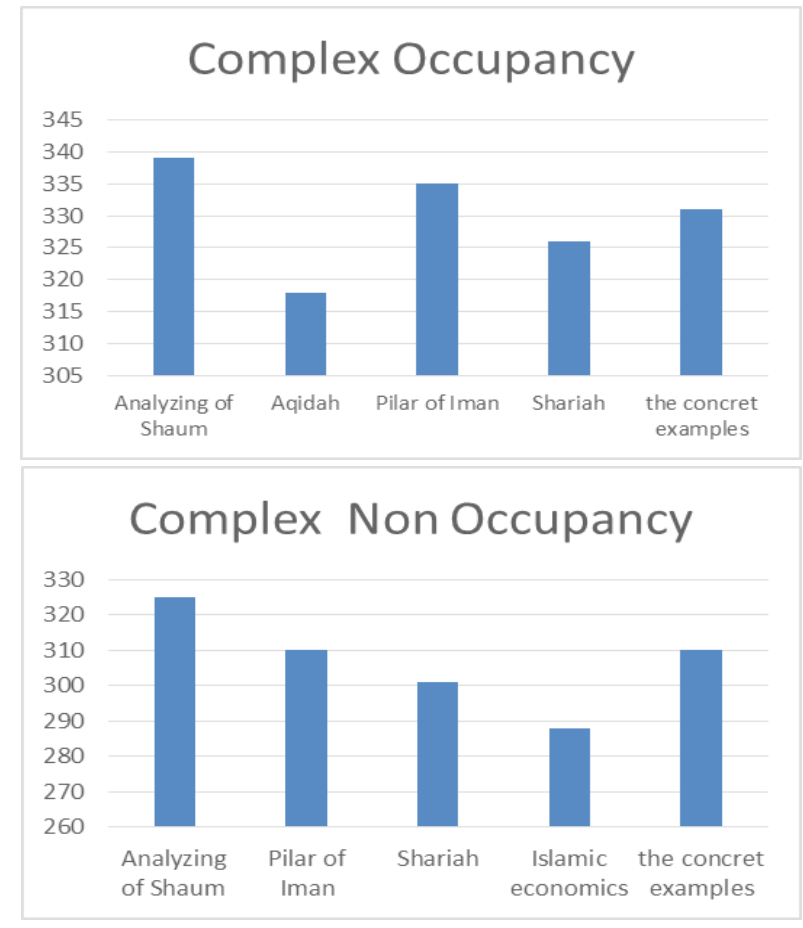

Source: Research Bambang S.Ma'arif, Cs, 2014

\section{Diagram 6. The Content of Dakwah Communication Message}

Based on diagram 6 the Content of Dakwah in zona more outskirts which divided to 2 occupancy classification, it can be categorized content of dakwah message that is satisfied by Dakwah Communican in Occupancy Complex is subject: Ramadhan and analyses of shaum, Pillar of Iman, analyzing religious teaching with the concret examples, Shariah Islam as the foundation of the truth ibadah and Aqidah. While the Dakwah communican at Non-Occupancy complex satisfied subject: Ramadhan dan analyses of shaum, Pilar of Iman, analyzing religious teaching with the concrete examples, Shariah Islam as the foundation of the truth amal ibadah, and analyses about Economy of Umat will be victorious if it is based on Islamic value.

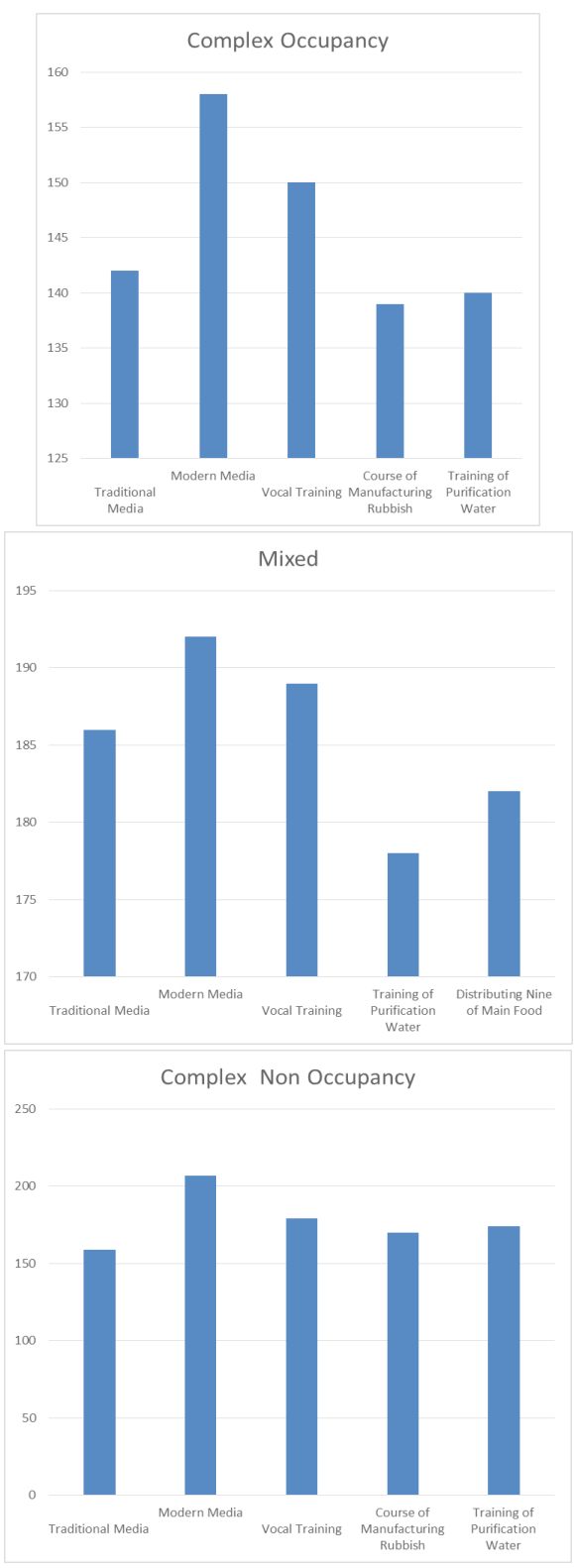

Source: Research Bambang S.Ma'arif, Cs, 2014

\section{Diagram 7. Media and Art of Dakwah Communication}

Based on diagram the Media and Art of Dakwah at Zona Count Side, and occupancy region (Complex Occupancy) satisfied modern Dakwah media, like slide photos, vocal training, dakwah traditional media (wayang), training of purification of water, course of manufacturing rubbish (trash). While nonOccupancy Complex satisfied: Art and Dakwah 
Media, use of modern dakwah media such as slide photos, The Dakwah Communication by means of training, training of purification of water, course of manufacturing rubbish (trash), dakwah traditional puppet media (wayang). The dakwah communican in countryside (which was mixed) satisfied the art and Dakwah Media use the modern dakwah media such as slide photos, vocal training, traditional media of dakwah [like puppet (wayang)], distributing nine main food, training of water purification.

\section{Zona of Edge of Town (more Out- skirts /Gedebage)}
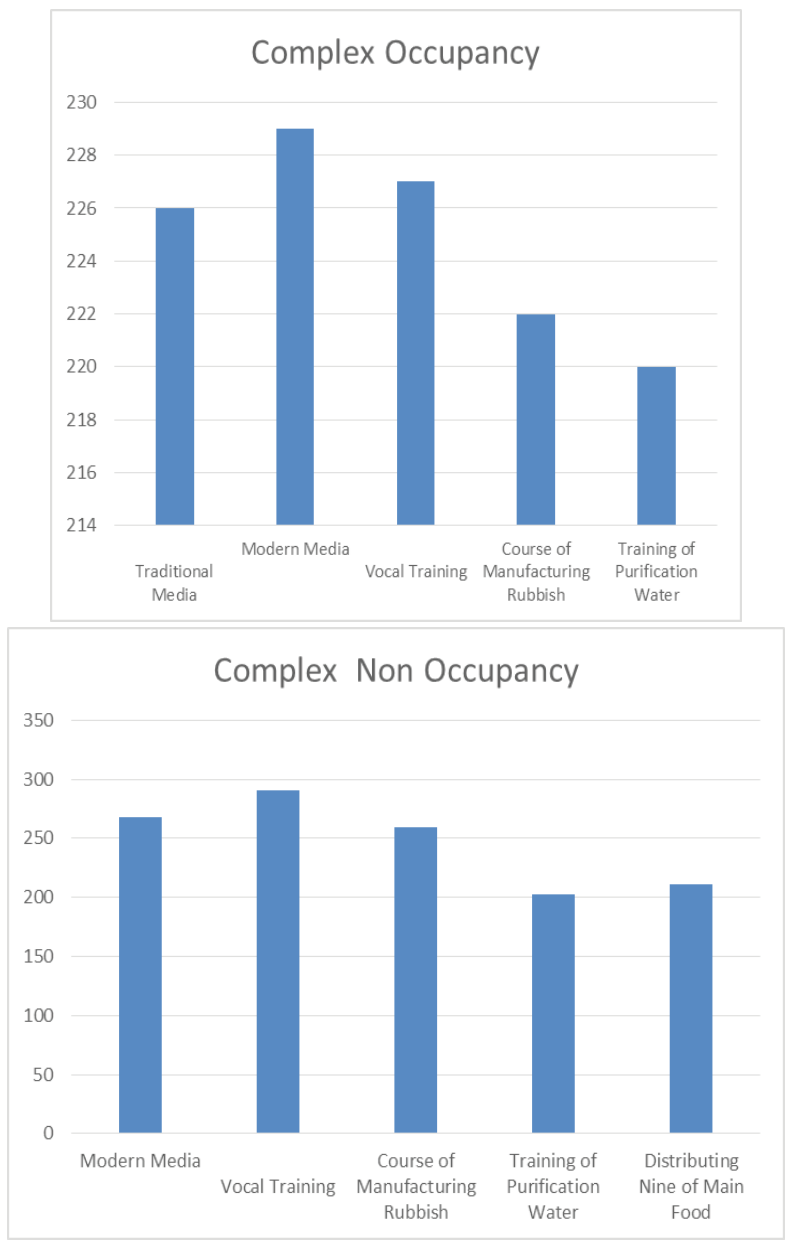

Source: Research Bambang S.Ma'arif, Cs, 2014

Diagram 8. Media and Art of Dakwah Communication

Based on diagram Media and Art of Dakwah Communicaion Zone Edge of town (Gedebage) which is satisfied by dakwah in Edge of town (Complex occupancy or Inhabitants): modern Dakwah Media, like slide photos, by means of training, uses traditional dakwah media [like puppet (wayang)], training of purification of water, course of manufacturing rubbish (trash). While Non-Occupancy complex satisfied Art and Dakwah Media and with the way of modern dakwah media, like slide photos, traditional dakwah media (such as puppet), by means of training, distributing nine of main food, course of manufacturing rubbish/trash.

\section{Analysis}

Scrutinizing data of this research result as presented at the earlier part, it can be presented the following analyze: The excellent Factor Socio-demography is related with Zona (region) Bandung which is necessary classified to become Central town, Countryside, and outskirts of city. The distribution is useful to exacerbates Dakwah Communication Profile Identification at this research. While SocioDemography of Dakwah Communication can possess different inclination between one group and another. This can be seen from the exist of different socio-demography condition that relates with behaviour of religious assembly (jemaah) live. Thus also relating Occupancy region (which interact with other sides), non-occupancy region, and occupancy (which has mixed), become profile which is identity to mapping assembly (al-jamā'ah) profile of dakwah communication pleased by assembly (al-jamā'ah).

The other socio-demographic factor of dakwah communican in Bandung comprise respondent identity (sex, age, education, occupation and religious behavior). The concerned factor is different between one group with another. So that form different accurate enjoyment upon dakwah communicator figure in Bandung city.

In this research, the writer also finds out that the information source about dakwah is quite different between one classification and another. All this aspect accurately shows map of profile of dakwah communication in Bandung, which is necessary to make basis of data for those agents on the whole. To make dakwah reach the target perfectly as according to their expectation upon persuasive dakwah of Islam. All this is necessary to make foundation of mapping dakwah communication in Bandung.

It means that there are several factors that must be understood to gain the persuasive dakwah upon the assembly. When we want to obtain the persuasively dakwah 
communication we ought to understand the socio-demographic factor as well as zone of city and the residence which they leave. It needs to be studied more intensively in the future day, and in another city. Because there may be several differences of cultures and frame of reference between one city and another one.

\section{Conclusions}

The researcher concludes various as follows: It is found that the prominent factor of Socio-demographic which becomes foundation for mapping dakwah activity in Bandung City, namely central town, countryside, and coastal area (outskirt of city), help mapping the dakwah activity profile. In the central town it is paid close attention to by means of dakwah communican occupancy, namely interacting occupancy complex interact without world [interact with market, Indonesian Army (TNI)-Airforce (AU) and non-market]; in Countryside there are occupancy, non-occupancy, and occupancy which mixed; in Coastal area there are occupancy and non occupancy beneficial for to make stirrup for dakwah comunication. The factor of dakwah communican sociodemography related with the pleasure of assembly to dakwah communication component which is different.

While the communican in central town (not interaction with market) is pleased by communicator with soft emotion, uses easy logic to be understood, polite language, produces a masterwork in society. While the communican in central town [Complex Indonesian Army-Air Force (TNI AU)] like dakwah communicator who produces a masterwork in society, speaks in polite language, uses easy logic to be understood, soft emotion, offers assist to assembly. The content of Dakwah Communcation which is liked by aljama'a(agregation) in Bandung city is different among the group at the three zones of region in Bandung with assembly in central town who interact with market like the content aqidah (faith) message, general election on dedicated leader, pilar of iman, religious analysis with samples, detriment of worship with riya (jealously or proud or haughty); which does not interact with market likes material or subject matter: aqidah (faith), analysis of religious with examples, pilar of iman, general election on dedicated leader, and practical explanation; and complex of Occupancy of Indonesian Army-Air
Force like material of aqidah (faith), general election, shariah Islam, akhlak or morals (inner condition) and society order, and akhlak (morals) forms character. Meanwhile, assembly in countryside in occupancy complex like aqidah material, explanation of Ramadhan fasting or shaum (because that the inquiry is spread out before Ramadhan), analysis of religious with examples, pillar of iman, and analysis about niat in ibadah; countryside non-occupancy the subject of shaum in Ramadhan month, aqidah (faith), pillar of iman, and general election for dedicated leader. The profile of dakwah communication in Bandung relatively differs among groups. This condition influences behavior dakwah communication in Bandung.

\section{References}

Abdul Khaliq, Abdurrahman. (1996). Metode dan Strategi Dakwah Islam. Jakarta: Pustaka al-Kautsar.

Abdurrahman. (2010). Recik-Recik Dakwah. Bandung: Sinar Baru Algesindo.

Abd. Rahman, Dudung. (2009). Kisi-Kisi Materi Bekal Dakwah. Bandung: Mujahid.

Albert, Jess K., Nakayama, Thomas K., dan Martin, Judith N. 2007. Human Communication in Society. Upper Saddle River NJ: Pearson Prentice Hall.

Al-Mubarakfuri, Syekh Safiyyurrahman. Perjalanan Hidup Rasul Yang Agung Muhammad Saw. dari Kelahiran Hingga Detik-Detik Terakhir. Jakarta: CV. Mulia Sarana Press.

Andrews, Patricia Bradley. (1985). Basic Public Speaking. New York: Harper and Row Publisher.

Astuti, Santi Indra. (2000). Pemanfaatan Radio sebagai Media Dakwah Jawaban atas Tantangan Berdakwah di Era Globalisasi, dalam Mimbar Jurnal Sosial dan Pembangunan. Unisba, Vol. 16 Nomor 3.

Fadhlullah, Muhammad Husain. (1997). Metodologi Dakwah dalam Al-Quran Pegangan bagi Para Aktivis. Jakarta: PT. Lentera Basritama.

Faizah, dan L. M. Effendi. (2009). Psikologi Dakwah. Jakarta: Rahmat Semesta.

Faridl, Miftah. (2008). Dakwah lain saukur Ceramah. Bandung: Pustaka MUI Jabar

Frager, Robert. (2012). Obrolan Sufi untuk Transformasi Hati, Jiwa dan Ruh. Jakarta: Zaman.

Hybels, Saundra, and Weaver II, Richard L. (1992). Communicating Effectively. New 
York: Mc-Graw-Hill, inc.

Islahi, Amin Ahsan. (1989). Serba-Serbi Dakwah. Bandung: Penerbit Pustaka.

Komala, Lukiati. (2009). Ilmu Komunikasi Perspektif, Proses dan Konteks. Bandung: Widya

$$
\text { Padjadjaran. }
$$

Maarif, Bambang Saiful. (2010). Komunikasi Dakwah Paradigma untuk Aksi. Bandung: Simbiosa Rekatama Media.

Markarma, A. (2014). Komunikasi Dakwah Efektif dalam Perspektif Al-Quran, dalam Hunafa: Jurnal Studia Islamica, Vol. 11 June, no. 1.

Muhtadi, Asep Saeful. (2012). Komunikasi Dakwah Teori, Pendekatan, dan Aplikasi. Bandung: Simbiosa Rekatama Media.

Pranggono, Bambang. (2006). Mozaik Dakwah Kumpulan Tulisan 1966 - 2006. Bandung: Khazanah Intelektual.

Rijal, Syamsul. (2005). Media and Islamism in post New Order Indonesia The Case of Sabily, in Studia Islamica Journal, Jakarta: UIN Ciputat.
Shimp, Terrance A., (2003). Advertising, Promotion and Suplemental Aspects of Integrated Marketing of Integrated Marketing Communication, sixth edition. Australia: Thomson.

Sobur, Alex. (2001). Dakwah Alternatif di Era Global: Suatu Pendekatan Perubahan Sosial, Mimbar Jurnal Sosial dan Pembangunan, Unisba, Volume 17 nomor 4.

Taimiyah, Ibnu. (2001). Manhaj Dakwah Salafiyah. Jakarta: Pustaka Azzam.

Verderber, Rudolph F. (1991). The Challenge of Effective Speaking. Belmont California: Wadsworth Publishing Company.

Wahyudi, Andi. (2012). Materi Kultum Penyejuk Hati. Solo: Tinta Medina.

Wood, Julia T. (2006). Communication in Our Lives, 4th edition. Australia: Thomson Wadsworth.

Zahrah, Abu (1994). Dakwah Islamiah. Bandung: Remadja Karya.

Zakaria, A. (2005). Materi Dakwah untuk Da'i dan Muballigh. Bandung: Risalah Press. 